\title{
VOLATILE OIL COMPOSITION OF AJUGA SPECIES OF NATURAL AND CULTIVATED ORIGIN IN THE LAKE DISTRICT OF TURKEY
}

\author{
DÖNMEZ, Ş. \\ Department of Landscape Architecture, Faculty of Architecture, Süleyman Demirel University \\ 32100 Isparta, Turkey \\ (e-mail: sirindonmez@sdu.edu.tr; phone: +90-246-211-3985; fax: +90-246-211-8231)
}

(Received 21 $1^{\text {st }}$ Jan 2019; accepted 20 $0^{\text {th }}$ Feb 2019)

\begin{abstract}
Leaves and flowers of Ajuga chamaepitys subsp. chia var. chia and Ajuga orientalis, which were taken from both their natural habitat and cultivars, were analyzed by SPME and GC-MS. The amount and the composition of volatile oil of cultivated plants were compared with natural area plants. $\beta$-pinene was detected as major component in A. chamaepitys in both natural habitat and cultivars. It was seen that its amount was between $17.86-25.21 \%$. Moreover, germacrene-D was determined in significant amount (15.40-21.13\%) in both samples of A. chamaepitys. 2-hexen-1-al was the most abundant component in the natural area (30.89\%) and cultivated plants (23.12\%) in the first vegetation period of A. orientalis but a decrease of almost $80 \%$ was determined in the second vegetation period. The amount of 1-octen-3-ol was found as one of the dominant components in A. orientalis and no significant difference was observed in both natural habitat and cultivars, during the vegetation periods. In addition, the amount of limonene in A. orientalis volatile oil increased in the second vegetation period compared to the first.
\end{abstract}

Keywords: Lamiaceae, SPME, GC-MS, pinene, germacrene, Turkey

\section{Introduction}

Volatile oil mainly consists of volatile components. It is fragrant, naturally occurring, colorless or light yellow and it is obtained from plants, leaves, fruits, bark and root parts, which are liquid and easily crystallizable (Ceylan, 1983). It is known that volatile oil contains a large amount of terpenes and a small amount of alcohols, aldehydes, esters and phenolics (Linskens and Jackson, 1997). There are many ways to reveal the volatile oil components of plants. Although distillation and extraction are quite wellknown methods, SPME (Solid Phase Micro Extraction) is used as it is new and easily applicable. It is suitable for both combining the sample preparation, extraction and concentration sections in a single step and for providing significant gains in processing time and cost. SPME is used to identify volatile organic compounds in the samples by combining with GC or GC-MS (Vas and Vekey, 2004).

Research on the volatile oil components of medicinal and aromatic plants has gained a significant place both scientifically and economically. In recent years, the use of volatile oil has also increased with the increase of interest in aromatherapy and phytotherapy, which is a branch of the alternative medicine (Rangahau, 2001).

Ajuga chamaepitys subsp. chia var. chia and Ajuga orientalis are species which belong to the Lamiaceae family. The Lamiaceae family grows almost everywhere in the Mediterranean climate without considering the plant type and height. Lamiaceae family has 400 genus and 3200 species around the world and it is represented by 45 genus and more than 546 species in Turkey. Among the species belonging to the Lamiaceae family, Thymus and Origanum have an important position in food industry, Pogestamon and Lavandula are considered in the perfume industry, and particularly the volatile oil 
of the species of Ajuga and Teucrium is used for therapeutic purposes (Watson and Dallwitz, 1978; Clive and Stace, 1980; Davis, 1982; Baytop, 1991; Ozkan, 2007).

Ajuga chamaepitys subsp. chia var. chia can grow up to $2000 \mathrm{~m}$ altitudes in Turkey, Crimea, Greece, Palestine, Iran and Northern Iraq (Davis, 1982). It is a herbaceous plant with a $20 \mathrm{~cm}$ length, yellow flowering and pleasant fragrant perennial suffrutescens (Baytop, 1999). The length of the shoots is $5-30 \mathrm{~cm}$. The whole plant is covered with white feathers and the flowers are yellow and the flowering time is between April and July (Akcan et al., 2006; Jakovljević et al., 2015; Dönmez et al., 2017).

Ajuga orientalis extends from Crimea to Sicily, West Syria, Cyprus, Caucasus and North West Iran. It can grow up to $2500 \mathrm{~m}$ from sea level in Mediterranean, Agean, Black Sea and Central Anatolia Regions in Turkey (Tekin, 2007). It is a perennial herbaceous plant with violet-blue and cream-colored flowers that can be sized up to $140 \mathrm{~cm}$ (Yazgin, 2010). The leaves are crossed on the trunk and rich in the lower part of the trunk. The flowering time is between April and May (Dönmez et al., 2017).

In this study, it was aimed to determine the composition and the amount of volatile oil and the yield of the same plant species in both natural habitat of the plants and their cultivars after the cultivation of $A$. chamaepitys subsp. chia var. chia and A. orientalis.

\section{Material and method}

\section{Material}

A. chamaepitys subsp. chia var. chia and A. orientalis, which belong to Lamiaceae family, were used for determining volatile oil yield and components. In the vegetation period of 2015, A. chamaepitys subsp. chia var. chia was taken from Aşağıöokdere, Isparta, where the altitude was $324 \mathrm{~m}\left(37^{\circ} 32^{\prime} 42^{\prime \prime} \mathrm{N}, 30^{\circ} 46^{\prime} 42^{\prime \prime} \mathrm{E}\right)$ and A. orientalis was removed from Kemer, Antalya, from an altitude of $413 \mathrm{~m}$. (36 $36^{\circ} 26^{\prime \prime} \mathrm{N}$, $30^{\circ} 27^{\prime} 53^{\prime \prime}$ E), with their roots. They were cultivated at Süleyman Demirel University (SDU), Botanical Garden by sowing. Plants, found in natural habitat and cultivars can be seen in Figure 1. In the vegetation period of 2016 and 2017, leaves and flowers of these plants, which were taken both from their natural habitat and cultivars at SDU, were used in the analyses of volatile oil production. The study area is located in the transition zone between the Mediterranean and terrestrial climate. According to data of Isparta Meteorological Station, the average annual temperature in the region was $12^{\circ} \mathrm{C}$. While the maximum temperature was $38.7^{\circ} \mathrm{C}$ in July, and the minimum was $-21^{\circ} \mathrm{C}$ in January. The mean annual precipitation amount was $508.3 \mathrm{~mm}$.

\section{Volatile Oil Yield}

In order to determine volatile oil yield, hydrodistillation with Clevenger apparatus was used. The material is directly immersed in water and it has direct contact with hot water and heat. For determining volatile oil yield of each species, $100 \mathrm{~g}$ ground samples were submitted to hydrodistillation for $5 \mathrm{~h}$ using a Clevenger apparatus. Volatile oil yield was calculated as $\mathrm{ml} / 100 \mathrm{~g}$ samples.

\section{SPME and GC-MS analyses}

The leaves and flower samples that were collected from both natural habitat and cultivars were put into paper packages and transferred to the laboratory in the same day to avoid exposure to sunlight and samples were subjected to solid phase microextraction 
(SPME). $2 \mathrm{~g}$ of samples were placed into a $10 \mathrm{ml}$ vial. After incubation for $30 \mathrm{~min}$ at $60^{\circ} \mathrm{C}$, SPME fibre was pushed through the headspace of a sample vial to absorb the volatiles and then inserted directly into the injection port of the GC-MS (Shimadzu 2010 Plus GC-MS with the capillary column, Restek Rxi ${ }^{\circledR}-5$ Sil MS 30 m x 0.25 mm, $0.25 \mu \mathrm{m}$ ) at a temperature of $250^{\circ} \mathrm{C}$ for desorption $(5 \mathrm{~min}$ ) of the adsorbed volatile compounds. The constituents were identified using retention times of standard substances by aligning mass spectra with the data given in the Wiley, NIST Tutor, FFNSC library.
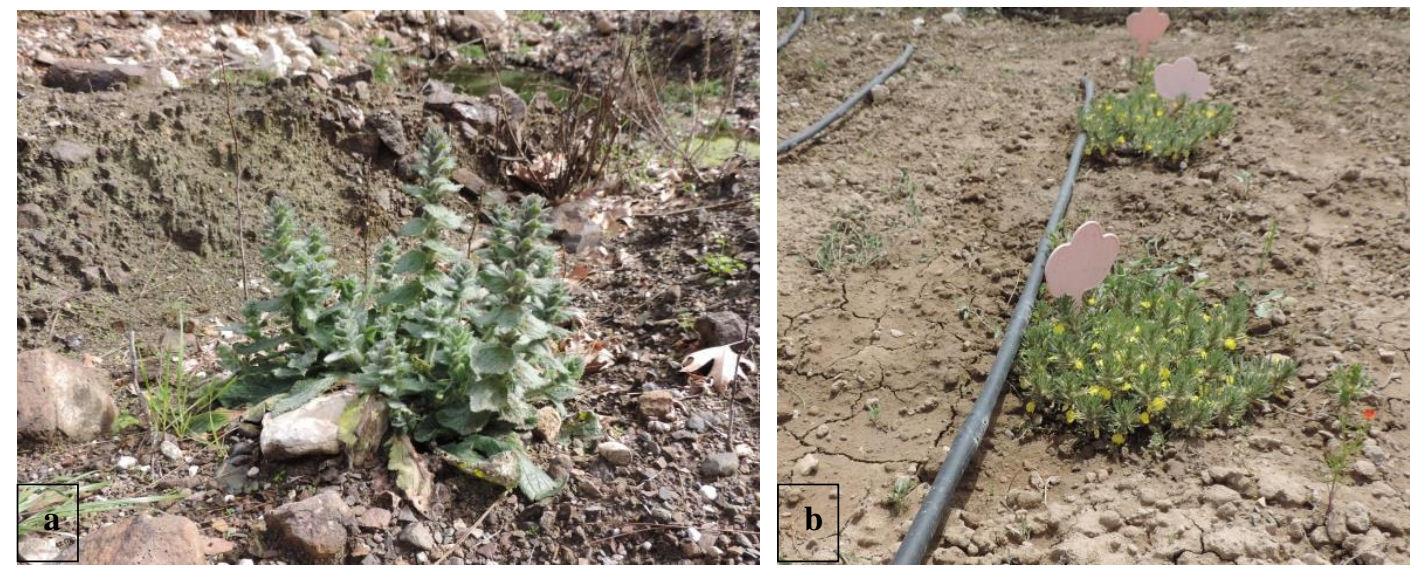

Figure 1. A view from both natural habitat (a) of A. orientalis and cultivation (b) of A. chamaepitys subsp. chia var. chia

\section{Results and discussion}

Analyses for getting volatile oil and determining volatile oil yield of both Ajuga species was performed in two vegetation periods (2016 and 2017) on the samples gathered from their natural habitat and cultivars at the same time. Volatile oil yield of both Ajuga species was determined after hydrodistillation. It was found that volatile oil yield of A. chamaepitys subsp. chia var. chia was determined very close in both samples during two vegetation periods. It was determined as $0.10 \mathrm{ml} / 100 \mathrm{~g}$ in natural area plants and $0.15 \mathrm{ml} / 100 \mathrm{~g}$ in field area plants in the first vegetation period. Moreover, it was $0.10 \mathrm{ml} / 100 \mathrm{~g}$ in both samples in the second vegetation period.

The volatile components in the leaves and flowers of Ajuga species collected from the sampling plots were identified through gas chromatography mass spectroscopy (GCMS) after solid phase micro extraction (SPME).

The amount and the composition of volatile oil of A. chamaepitys subsp. chia var. chia can be seen in Table 1. 41 components in the samples from natural habitat and 39 components in the samples from cultivars of the first vegetation period were determined. However, 50 and 49 components, respectively, were identified in the second vegetation period. $\beta$-pinene was determined as the dominant component in all samples in both vegetation period of A. chamaepitys subsp. chia var. chia. While its amount was $19.15 \%$ in natural habitat and $17.86 \%$ in the samples from cultivars in the first vegetation period, it was found $22.25 \%$ in in natural habitat and $25.21 \%$ in the samples from cultivars in the second vegetation period. Germacrene-D was the second component having highest amount. It was seen that its amount increased in the second vegetation period compared to the first vegetation period. 
Table 1. The amount and the composition of A. chamaepitys subsp. chia var. chia volatile compounds (\%)

\begin{tabular}{|c|c|c|c|c|}
\hline \multirow{3}{*}{ Compounds } & \multirow{2}{*}{\multicolumn{2}{|c|}{$\frac{\text { 1st Vegetation Period }}{\text { Amount }(\%)}$}} & \multirow{2}{*}{\multicolumn{2}{|c|}{$\begin{array}{c}\text { 2nd Vegetation Period } \\
\text { Amount }(\%)\end{array}$}} \\
\hline & & & & \\
\hline & Natural Area & Field Area & Natural Area & Field Area \\
\hline 2-ethyl-Furan & 0.22 & 0.43 & - & - \\
\hline Me-acetate & - & - & 0.46 & 0.44 \\
\hline Linalyl acetate & - & - & 0.08 & 0.04 \\
\hline Acetic acid & - & - & 0.09 & 0.13 \\
\hline Me-propyl ketone & - & - & 0.04 & 0.09 \\
\hline Me-heptyl ketone & - & - & 0.09 & 0.12 \\
\hline n-Hexanal & 0.48 & 0.78 & - & - \\
\hline 2-Hexen-1-al & 4.09 & 3.39 & - & 0.08 \\
\hline 3-Hexene-1-ol & 0.22 & 0.32 & 0.45 & 0.11 \\
\hline 2-Hexen-1-ol & - & - & - & 0.10 \\
\hline $\mathrm{n}$-Hexanol & - & - & - & 0.07 \\
\hline 1,4-Cyclohexadiene & - & - & 0.54 & 0.28 \\
\hline 2,4-Hexadienal & 0.81 & 0.51 & - & - \\
\hline$\alpha$-Thujene & 0.60 & 1.93 & 0.29 & 0.37 \\
\hline$\alpha$-pinene & 2.37 & 2.31 & 2.98 & 3.45 \\
\hline$\beta$-phellandrene & 0.31 & - & - & - \\
\hline Benzaldehyde & - & 0.20 & 0.02 & 0.03 \\
\hline Sabinene & - & 0.64 & 0.29 & 0.34 \\
\hline$\beta$-pinene & 19.15 & 17.86 & 22.25 & 25.21 \\
\hline 1-Octen-3-ol & 4.75 & 11.69 & 0.32 & 0.29 \\
\hline$\beta$-Myrcene & 10.53 & 13.33 & - & - \\
\hline Myrcene & - & - & 5.15 & 5.55 \\
\hline Ethyl-hexanol & 0.19 & 1.00 & 1.52 & - \\
\hline 1-Phellandrene & 0.37 & 0.95 & - & - \\
\hline 2,4-Heptadienal, & 0.37 & 0.61 & - & - \\
\hline p-cymene & - & 1.16 & 0.98 & 0.33 \\
\hline Me-cymol & 0.14 & - & 1.23 & - \\
\hline Limonene & 4.64 & 4.36 & 5.97 & 6.42 \\
\hline Trans-limonene oxide & - & - & 0.41 & 0.04 \\
\hline Ocimene & 0.25 & 0.23 & - & - \\
\hline$\beta$ - ocimene & 1.83 & 1.00 & 1.10 & 1.37 \\
\hline$\alpha$-terpinolene & 0.22 & - & 0.05 & 0.07 \\
\hline 1,6-Octadien-3-ol & - & 0.75 & 1.98 & - \\
\hline Nonanal & - & 0.26 & - & - \\
\hline Dodecane & - & - & 0.12 & 0.08 \\
\hline Butanoate & - & - & 0.02 & 0.02 \\
\hline 1-linalool & 0.96 & - & 0.45 & 0.56 \\
\hline p-Mentha-1,5,8-triene & 0.27 & 0.27 & - & - \\
\hline 2-Pinen-3-one & - & 0.22 & - & - \\
\hline 2,4,6-octatriene & 0.23 & - & - & - \\
\hline Benzoic acid & 0.31 & - & - & - \\
\hline Tridecane & 0.20 & - & 0.07 & 0.07 \\
\hline$\alpha$-Cubebene & 0.53 & 0.76 & 0.60 & 0.69 \\
\hline Copaene & 3.71 & 8.10 & - & - \\
\hline$\alpha$-Copaene & - & - & 10.25 & 11.56 \\
\hline$\beta$-bourbonene & 3.10 & 5.14 & 4.96 & 5.03 \\
\hline$\alpha$-Gurjunene & 0.12 & - & 0.78 & 0.80 \\
\hline $\begin{array}{l}\text { 1,2,4,5-tetramethyl-6-methylene- } \\
\text { spiroheptane }\end{array}$ & 0.14 & - & - & - \\
\hline$\beta$-caryophyllene & - & 3.01 & 1.03 & - \\
\hline$\alpha$-Amorphene & 0.33 & - & 0.62 & - \\
\hline$\alpha$-Chamigrene & 0.26 & - & - & - \\
\hline p-Allylanisole & - & - & 0.02 & 0.03 \\
\hline Cyclosativene & - & - & 0.09 & 0.08 \\
\hline$\beta$-cubebene & - & 0.95 & 0.52 & 0.15 \\
\hline$\alpha$-Himachalene & - & 0.34 & - & - \\
\hline Caryophyllene & 12.17 & - & 5.82 & 5.99 \\
\hline Germacrene-D & 19.04 & 15.40 & 19.63 & 21.13 \\
\hline$\beta$-Farnesene & - & 0.48 & - & - \\
\hline Epi-bicyclo sesquiphellandrene & 0.69 & 0.44 & - & 0.47 \\
\hline bicyclogermacrene & 2.57 & 0.55 & 0.98 & 1.08 \\
\hline
\end{tabular}




\begin{tabular}{|c|c|c|c|c|}
\hline \multirow{3}{*}{ Compounds } & \multirow{2}{*}{\multicolumn{2}{|c|}{$\begin{array}{c}\text { 1st Vegetation Period } \\
\text { Amount }(\%)\end{array}$}} & \multirow{2}{*}{\multicolumn{2}{|c|}{$\begin{array}{c}\text { 2nd Vegetation Period } \\
\text { Amount }(\%)\end{array}$}} \\
\hline & & & & \\
\hline & Natural Area & Field Area & Natural Area & Field Area \\
\hline$\alpha$-Guaiene & - & - & 0.03 & 0.04 \\
\hline$\beta$-elemene & - & - & 0.02 & 0.02 \\
\hline Torreyol & - & - & 0.09 & 0.07 \\
\hline Eucalyptol & - & - & 0.21 & 0.05 \\
\hline Solanone & - & - & 0.03 & 0.03 \\
\hline$\alpha$-farnesene & 0.50 & - & 0.63 & - \\
\hline Farnesene & - & - & - & 0.19 \\
\hline$\alpha$-Muurolene & - & 0.45 & 0.22 & 0.38 \\
\hline Caryophyllene oxide & 0.39 & 0.22 & - & - \\
\hline$\gamma$-Cadinene & 0.70 & 0.96 & 3.12 & 4.75 \\
\hline 1,4-Cadinadiene & - & - & - & 0.55 \\
\hline trans-Pinocarveol & - & - & 0.14 & 0.09 \\
\hline$\delta$-cadinene & 1.17 & 1.27 & 0.48 & 0.74 \\
\hline$\alpha$-Patchoulene & - & 0.20 & - & - \\
\hline$\alpha$-humulene & 0.84 & - & 0.34 & 0.41 \\
\hline Alloaromadendrene & 0.22 & 0.31 & 0.49 & - \\
\hline
\end{tabular}

The amount of germacrene-D was $19.04 \%$ in the samples from natural habitat and $15.40 \%$ in the samples from cultivars in the first vegetation period. However, it was detected $19.63 \%$ and $21.13 \%$, respectively, in the second vegetation period.

Although $\beta$-myrcene was determined only in the first vegetation period in both sampling areas, myrcene was seen only in the second vegetation period samples. Besides, caryophyllene was detected only in natural habitat samples with the amount of $12.17 \%$ in the first vegetation period. In the second vegetation period, the amount of caryophyllene decreased almost 50\% compared to the first vegetation period samples. It was found $5.82 \%$ in the samples from natural habitat whereas it was $5.99 \%$ in the samples from cultivars.

Volatile oil of Ajuga species were determined by several researches. Azizan et al (2002) determined volatile oil components of A. chamaepitys subsp. chia var. chia by hydrodistillation. Totally 25 components were identified and $\alpha$-pinene (16.1\%), $\beta$-pinene $(34.38 \%)$ and germacrene-D $(5.6 \%)$ were found as the dominant components. Saijadi and Ghanhadi (2004) found germacrene-D (24.2\%), $\beta$-cubebene $(18.3 \%)$, $\beta$-caryophyllene $(16.9 \%)$ and $\alpha$-cubebene $(5.3 \%)$ as the highest in A. chamaepitys subsp. chia var. chia volatile oil. It was another study done by Delazar et al (2012) in which $\alpha$-pinene $(23.66 \%), \beta$-pinene $(9.33 \%), \beta$-phellandrene $(8.70 \%)$ and germacrene-D (7.92\%) were the dominant components of Iranian A. chamaepitys subsp. chia var. chia volatile oil.

Volatile oil yield of $A$. orientalis was $0.10 \mathrm{ml} / 100 \mathrm{~g}$ in the samples from natural habitat and $0.05 \mathrm{ml} / 100 \mathrm{~g}$ in the samples from cultivars in the first vegetation period. In the second vegetation period, volatile oil yield of natural habitat samples was $0.15 \mathrm{ml} / 100 \mathrm{~g}$ while it was the same as the former in the samples from cultivars. The amount and the composition of A. orientalis volatile oil determined by SPME and GCMS can be seen in Table 2. In both samples of the first vegetation period, 44 components were identified. However, the identified components were 40 in the samples from natural habitat and 53 in the samples from cultivars in the second vegetation period.

While 2-hexen-1-al had the maximum amount in the first vegetation period in the samples from natural habitat, 1-octen-3-ol was determined as the highest amount component in the samples from cultivars. 
Table 2. The amount and the composition of A. orientalis volatile compounds (\%)

\begin{tabular}{|c|c|c|c|c|}
\hline \multirow{3}{*}{ Compounds } & \multicolumn{2}{|c|}{ 1st Vegetation Period } & \multicolumn{2}{|c|}{ 2nd Vegetation Period } \\
\hline & \multicolumn{2}{|c|}{ Amount (\%) } & \multicolumn{2}{|c|}{ Amount (\%) } \\
\hline & Natural Area & Field Area & Natural Area & Field Area \\
\hline Acetaldehyde & 0.29 & 0.22 & 1.51 & 1.31 \\
\hline Borane-methyl sulfide complex & 0.55 & 0.33 & 1.97 & 1.22 \\
\hline Amyl ethyl ketone & - & - & 1.53 & 1.03 \\
\hline 2-Butenal & 1.32 & 0.90 & 0.41 & 0.26 \\
\hline 3-Methylbutanal & 0.48 & 0.65 & 0.47 & 0.61 \\
\hline 2-Methylbutanal & 0.33 & 0.61 & 0.47 & 0.52 \\
\hline 4-methylpentanenitrile & 0.50 & 0.50 & - & 0.33 \\
\hline 2-ethyl-Furan & 1.14 & 1.01 & - & 0.89 \\
\hline 2-pentanal & 0.54 & 0.25 & - & 0.33 \\
\hline 2-Penten-1-ol & 0.70 & 0.98 & - & 0.41 \\
\hline n-Hexanal & 3.85 & 4.22 & 1.42 & 1.26 \\
\hline 2-Hexen-1-al & 30.89 & 23.12 & 6.19 & 7.23 \\
\hline 3-Hexene-1-ol & 1.42 & 3.43 & - & - \\
\hline 2-Hexen-1-ol & 0.87 & 1.90 & - & - \\
\hline n-Hexanol & 2.24 & 3.54 & 1.10 & 0.91 \\
\hline Styrene & - & - & 0.94 & 0.86 \\
\hline 4-hepten-1-al & 0.29 & 1.12 & 1.00 & 1.23 \\
\hline Heptanal & 0.26 & 0.42 & - & 0.33 \\
\hline 2,4-Hexadienal & 0.83 & 0.99 & - & 0.67 \\
\hline$\alpha$-pinene & 0.98 & 1.12 & 8.29 & 7.46 \\
\hline Phenylmenthanal & - & - & 1.28 & 0.98 \\
\hline 2-heptanal & 0.44 & 0.81 & 0.40 & 0.31 \\
\hline Benzaldehyde & 1.26 & 1.22 & - & 0.83 \\
\hline Sabinene & 0.26 & 0.83 & 0.33 & 0.22 \\
\hline 1-hexene & 0.97 & 0.56 & - & - \\
\hline$\beta$-pinene & - & - & 0.65 & 0.58 \\
\hline Vinyl amyl ketone & - & - & 0.52 & 0.49 \\
\hline 1-Octen-3-ol & 26.30 & 28.34 & 28.16 & 26.79 \\
\hline$\beta$-Myrcene & 2.58 & 3.01 & 4.84 & 3.86 \\
\hline 2,4-Heptadienal, & 3.21 & 4.56 & 1.28 & 1.03 \\
\hline 2,2-Pentenylfuran & 0.39 & 0.44 & - & - \\
\hline Ethyl-hexanol & 0.85 & 1.01 & - & - \\
\hline n-octanal & 0.57 & 1.67 & - & - \\
\hline$\delta 3$-carene & 1.14 & 1.85 & 3.42 & 3.01 \\
\hline n-octan-3-ol & - & - & 1.71 & 1.77 \\
\hline 1-hexyl acetate & - & - & 1.03 & 1.01 \\
\hline Hexyl-Ethanoate & 2.00 & 1.12 & - & 0.98 \\
\hline Cymol & - & - & 0.73 & 0.61 \\
\hline Limonene & 3.64 & 2.56 & 12.36 & 11.69 \\
\hline Trans-limonene oxide & - & - & - & 1.03 \\
\hline Hyacinthin & - & - & 0.32 & 0.21 \\
\hline 2-octenal & 0.50 & 1.32 & - & - \\
\hline 3,5-octadien-2-one & 0.93 & 1.22 & 0.69 & 0.41 \\
\hline$\alpha$-terpinolene & 0.30 & 0.10 & 2.51 & 1.89 \\
\hline Nonanal & 2.76 & 0.99 & 0.27 & 0.64 \\
\hline Dodecane & 0.30 & 0.10 & 0.59 & 0.24 \\
\hline n-Decanal & 0.48 & 0.55 & 0.26 & 0.63 \\
\hline Benzene & 0.75 & 0.62 & - & - \\
\hline n-Octyl acetate & 0.70 & 0.81 & - & 0.83 \\
\hline hexyl 2-methylbutanoate & 0.51 & 0.23 & - & 0.44 \\
\hline 1-linalool & 0.45 & 0.12 & 0.68 & 0.43 \\
\hline Hexyl butanoate & - & - & 0.47 & 0.44 \\
\hline p-allylanisole & - & - & 0.23 & 0.23 \\
\hline n-octyl 2-methyl butyrate & 0.35 & 0.33 & - & 0.22 \\
\hline 3-Buten-2-one & 0.43 & 0.11 & - & 0.31 \\
\hline 2-Butenoic acid & 0.45 & 0.21 & 2.81 & 2.63 \\
\hline Pentanoic acid & - & - & 1.09 & 0.93 \\
\hline Tridecane & - & - & 0.64 & 0.66 \\
\hline Tetradecane & - & - & 1.37 & 1.29 \\
\hline Valencene & - & - & 1.45 & 1.53 \\
\hline$\alpha$-farnesene & - & - & 3.76 & 3.11 \\
\hline
\end{tabular}


Moreover, 1-octen-3-ol was also dominant component of the second vegetation period samples with $28.16 \%$ in natural habitat and $26.79 \%$ in cultivars. Volatile oil composition and antimicrobial activity of Ajuga orientalis was presented by Yaldiz (2012). It was seen that germacrene-D, cubebene and caryophyllene were the major components of $A$. orientalis volatile oil.

\section{Conclusions}

A. chamaepitys subsp. chia var. chia and Ajuga orientalis, which grow naturally in Lake District in Turkey, were cultivated in 2015. Volatile oil analyses were carried out in 2016 and 2017 by using leaves and flowers of these plant species from both natural habitat and cultivars. It was seen that there were same components and the amount of components were close to each other in both sampling areas. It was concluded that these plants were cultivated without losing their chemical structure. This is a particularly important result for these two plant species belonging to the Lamiaceae family, which are known to be used as medicinal and aromatic plants. In this direction, it is thought that these plants can be produced in industrial sense and can also be used in different industries such as pharmaceuticals and cosmetics due to their chemical composition.

Acknowledgements. This work is a part of a project supported by The Scientific and Technological Research Council of Turkey (TUBITAK) with the project number 114O345. The author thanks to Doc. Dr. İlhami Emrah Dönmez, Department of Forest Products Engineering, ISUBU, Turkey, for his support and discussing on the analyses.

\section{REFERENCES}

[1] Akcan, O. E., Senel, G., Akcan, Y. (2006): The Morphologial and Anatomical Proporties of Ajuga chamaepitys (L.) SCHEBER subsp. chia (SCHEBER) ARCANGELI var. chia (SCHEBER) ARCANGELI and Ajuga reptans L. Taxa. - Pakistan Journal of Biological Sciences 9(2): 289-293.

[2] Azizan, J., Fallah-Bagher-Shaidaei, H., Kefayeti, H. (2002): Chemical Constituents of the Essential Oil of Ajuga chamaepitys Growing in Iran. - Journal of Essential Oil Research 14(5): 344-345.

[3] Baytop, T. (1991): Farmasotik Botanik Ders Kitab1. - Istanbul University Press, Istanbul.

[4] Baytop, T. (1999): Türkiye'de Bitkilerle Tedavi Geçmişte ve Bugün. - Nobel Tıp Kitabevleri Yayınları, 480s, İstanbul.

[5] Ceylan, A. (1983): Tıbbi Bitkiler-II. - Ege Üniversitesi Ziraat Fakültesi Yayını No:481, Bornova-İzmir.

[6] Clive, A., Stace, C. (1980): Plant Taxonomy and Biosistematics. - Cambridge University.

[7] Davis, P. H. (1982): Flora of Turkey and The East Aegaen Islands. 7. - Edinburg University Press, Eurasian J. Agric \& Environ Sci. 5(6): 843-846.

[8] Delazar, A., Delnavazi, M., Yassa, N., Parkhideh, S., Delazar, N., Nahar, L., Sarker, S. D. (2012): Essential oil composition and isolation of free- radical-scavenging phenolic glycosides from the aerial parts of Ajuga chamaepitys growing in Iran. - Brazilian Journal of Pharmacognosy 22(2): 299-305.

[9] Dönmez, Ş., Basıç, G., Fakir, H., Özçelik, H., Yazıcı, N., Kuş Şahin, C., Gül, A., Dönmez, İ. E. (2017): Visual Characteristics of Some Species Belonging To The Family of Lamiaceae in The Lake District. - International Journal of Engineering Sciences \& Research Technology (6)12: 256-261. 
[10] Jakovljević, D. Z., Vasić, S. M., Stanković, M. S., Čomić, L. R., Topuzović, M. D. (2015): Secondary Metabolite Content And In Vitro Biological Effects of Ajuga chamaepitys (L.) subsp chamaepitys. - Arch. Biology Sciciences, Belgrade 67(4): 11951202.

[11] Linskens, H. F., Jackson, J. F. (1997): Modern Methods of Plant Analysis. - Plant Volatile Analysis, Springer, Vol. 19, Germany.

[12] Ozkan, G. (2007): Determination of phenolic components, antioxidant and antibacterial effects of some plants used herb or condiment belonging to Lamiacea (Labiatea) family in Turkey. - Selçuk University, Graduate School of Natural and Applied Sciences, PhD thesis, Konya.

[13] Rangahau, M. K. (2001): Essential oils and their production. - Crop and Food Research, Nr. 39, October.

[14] Saijadi, S. E., Ghannadi, A. (2004): Volatile Oil Composition of the Aerial Parts of Ajuga orientalis L. from Iran" - Journal of Biosciences 59(3-4): 166-168.

[15] Tekin, E. (2007): Türkiye'nin En Güzel Yabani Çiçekleri. - Ankara: Türkiye İş Bankası Yayınları.

[16] Vas, G., Vekey, K. (2004): Solid-Phase Microextraction: Apowerful Sample Preparation Tool Prior To Mass Spectrometric Analysis. - Journal of Mass Spectrometry 39: 233254.

[17] Watson, L., Dallwitz, M. T. (1978): The Families of Flowering Plants. - Oxford University Press, London.

[18] Yaldiz, G. (2012): Some Antimicrobial Activity Plants Growing in Rize Region Used in Alternative Medicine. - Journal of Life Sciences 6: 624-631.

[19] Yazgın, A. (2010): Bazı Teucrium L. (Lamiaceae) Türlerinin Kemotaksonomik Yönden Araştırılması. - Fırat Üniversitesi Fen Bilimleri Enstitüsü, Biyoloji Anabilim Dalı, Yüksek Lisans Tezi, Malatya. 